\title{
Epigenetic regulation of cancer biology and anti-tumor immunity by EZH2
}

\author{
Anthos Christofides ${ }^{1,2, *}$, Theodoros Karantanos ${ }^{1,2,3, *}$, Kankana Bardhan ${ }^{1,2}$ and \\ Vassiliki A. Boussiotis ${ }^{1,2}$ \\ ${ }^{1}$ Division of Hematology-Oncology, Beth Israel Deaconess Medical Center, Boston, MA, USA \\ 2 Department of Medicine Beth Israel Deaconess Medical Center, Harvard Medical School, Boston, MA, USA \\ ${ }^{3}$ General Internal Medicine Section, Boston Medical Center, Boston University School of Medicine, Boston, MA, USA \\ * First co-authors listed alphabetically
}

Correspondence to: Vassiliki A. Boussiotis, email: vboussio@bidmc.harvard.edu

Keywords: cancer biology, epigenetics, EZH2, cancer immunology

Received: August 05, $2016 \quad$ Accepted: October 13, $2016 \quad$ Published: October 26, 2016

\section{ABSTRACT}

Polycomb group proteins regulate chromatin structure and have an important regulatory role on gene expression in various cell types. Two polycomb group complexes (Polycomb repressive complex 1 (PRC1) and 2 (PRC2)) have been identified in mammalian cells. Both PRC1 and PRC2 compact chromatin, and also catalyze histone modifications. PRC1 mediates monoubiquitination of histone H2A, whereas PRC2 catalyzes methylation of histone $\mathrm{H3}$ on lysine 27 . These alterations of histones can lead to altered gene expression patterns by regulating chromatin structure. Numerous studies have highlighted the role of the PRC2 catalytic component enhancer of zeste homolog 2 (EZH2) in neoplastic development and progression, and EZH2 mutations have been identified in various malignancies. Through modulating the expression of critical genes, EZH2 is actively involved in fundamental cellular processes such as cell cycle progression, cell proliferation, differentiation and apoptosis. In addition to cancer cells, EZH2 also has a decisive role in the differentiation and function of $\mathrm{T}$ effector and $T$ regulatory cells. In this review we summarize the recent progress regarding the role of EZH2 in human malignancies, highlight the molecular mechanisms by which EZH2 aberrations promote the pathogenesis of cancer, and discuss the anti-tumor effects of EZH2 targeting via activating direct anti-cancer mechanisms and anti-tumor immunity.

\section{INTRODUCTION}

The term Polycomb $(P c)$ initially referred to a Drosophila mutant that displayed improper body segmentation. Based on this observation it was suggested that Polycomb encodes a negative regulator of the homeotic genes that are required for segmentation [1]. Now, it is known that the Polycomb group (PcG) defines a set of genes characterized by mutations that result in similar phenotypes to those of Polycomb but has extended its functions from Drosophila to mammalian cells [2]. The crucial role of PcG proteins during development is highlighted by early embryonic lethality in mice after the deletion of genes encoding some of these proteins ( $E e d$, Ezh2 (also known as Enx-1), Suz12 and Ring1B (Rnf2)).
PcG proteins are found in several families of multiprotein complexes, including the Polycomb repressive complexes, which form two closely related complexes, PRC1 and PRC2. PRCs mediate gene silencing mainly by regulating chromatin structure through posttranslational modification (PTM) of histones. The PRC2 complex is responsible for trimethylation of Lys 27 of histone $\mathrm{H} 3$ (H3K27me3) through its enzymatic subunits EZH1 and EZH2, which are core components of PRC2. H3K27me3 plays an important role in epigenetic gene silencing, particularly in homeobox (Hox) gene loci. The methyltransferase activity of EZH2 is provided by the signature SET domain, located at the $\mathrm{COOH}$-terminus. Importantly, EZH2 lacks enzymatic function and must partner with at least three noncatalytic proteins, including 
EED, SUZ12 and RbAp48/46, to form the PRC2 complex, which has potent histone methyltransferase activity [3] (Figure 1). Subsequently, it was determined that AEBP2, PCL and JARID2 are also components of the PRC2 complex. Although these additional components might be necessary for optimal PRC2 activity, their precise role has not been fully elucidated. EZH1 also forms a PRC2 complex. EZH2 is present only in dividing cells, whereas EZH1 is found both in dividing and non-dividing cells. The PRC2 complexes, which contain EZH1, have low methyltransferase activity compared to PRC2 complexes, which contain EZH2. The PRC1 complex is responsible for monoubiquitylation of Lys 119 of histone H2A (H2AK119ub) via the ubiquitin ligases RING1A and RING1B. PRC1 occupies some of the PRC2 sites [4] and may function downstream of PRC2 [2]. In contrast to the limited knowledge about the role and functions PRC1 in mammalian cells, PRC2 has been extensively studied and its key role in cell differentiation and fate determination is well established. The PRC2 complex has evolved not only as a key regulator of cell differentiation and plasticity during evolution but also as a molecular mediator of cancer development and a novel target of cancer treatment.

The sequencing of the cancer genome has revealed that genes encoding chromatin regulators are frequently mutated in solid tumors and hematologic malignancies highlighting the role of these molecules in the development and progression of human neoplasms [5-7]. Alterations of histone methylation and acetylation mediated by chromatin modulators can lead to down-regulation of tumor suppressor genes and overexpression of oncogenes implicated in the development and progression of malignancies [8]. Moreover, chromatin modulators are involved in oncogenic signaling independently of their role in epigenetic regulation and have been directly associated with activation of intracellular pathways leading to cell proliferation, apoptosis inhibition and cancer progression. Several recent studies have highlighted the role of EZH2 in neoplastic development and progression while this molecule has been associated with poor prognosis in a

A

PRC2

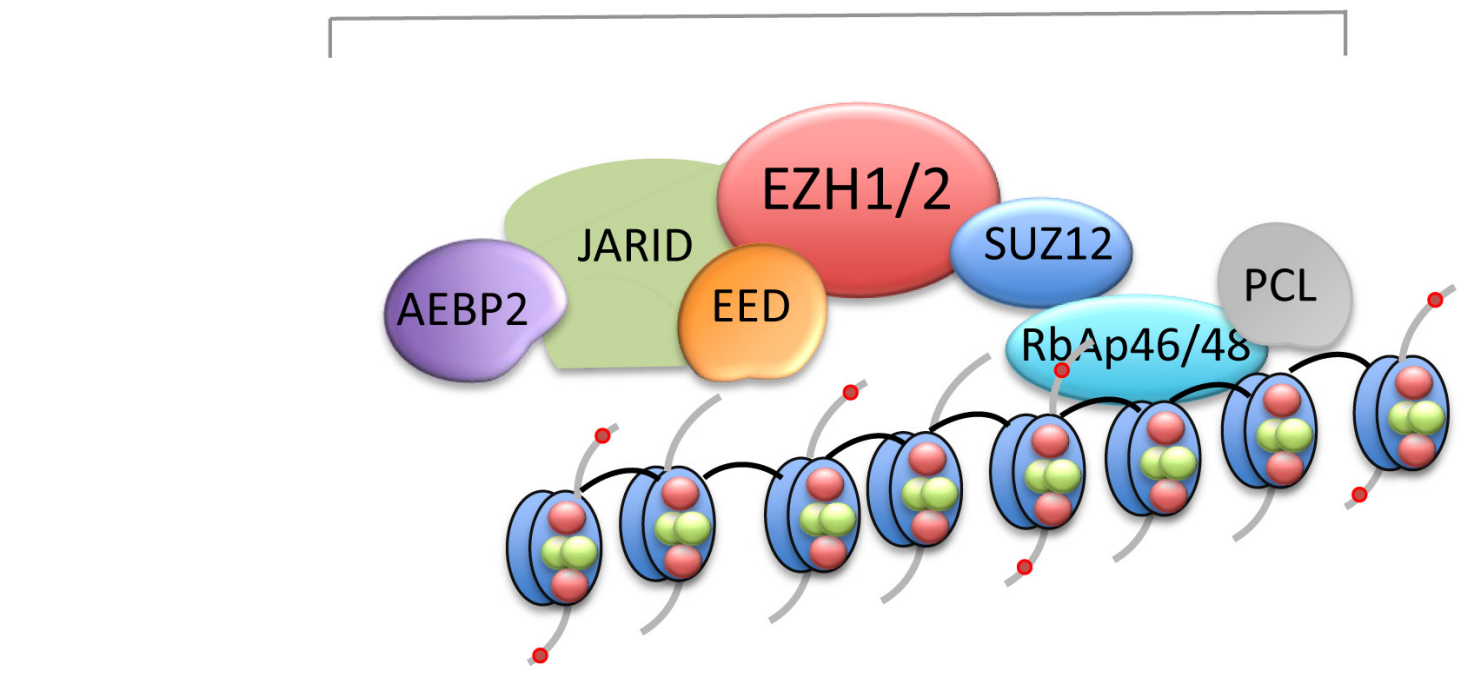

B

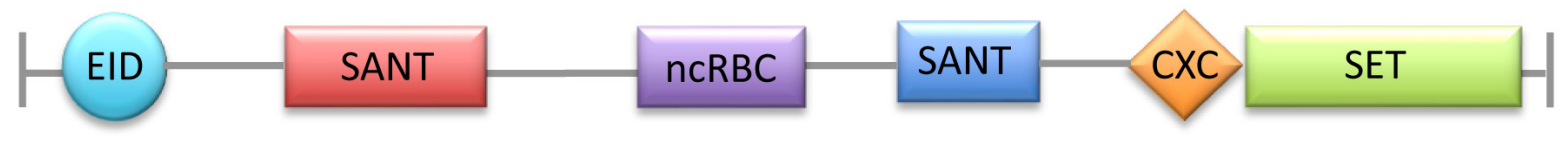

Figure 1: A. The polycomb complex PRC2. PRC2 contains EZH2 or EZH1 and four key components, EED, EZH1/2, Suz12 and RbAp46/48, which are required for its enzymatic activity. AEBP2, PCL and JARID2 are also components of the PRC2 complex but their precise role is currently unclear. B. Characterized domains of EZH2. EID, EED interaction domain; SANT, SWI3, ADA2, N-CoR and TFIIIB DNA-binding domain; ncRBD, non-coding-RNA-binding domain; CXC, cysteine-rich domain; SET, Su(var)3-9, enhancer of zeste, trithorax domain. 
variety of human malignancies.

EZH2, the catalytic subunits of the PRC2 catalyzes the methylation of histone $\mathrm{H} 3$ lysine 27 to form H3K27me3 by its C-terminal SET domain [9], promoting transcriptional silencing through development of repressive marks on the promoters of target genes [2]. Through modulating the expression of critical genes, EZH2 is actively involved in fundamental cellular processes such as cell cycle progression, cell proliferation, cell differentiation and apoptosis. EZH2 mutations have been found in various malignancies, while EZH2 expression levels are associated with the prognosis of human neoplasms suggesting the potential involvement of EZH2 in the development and progression of cancer [10]. The interest in better understanding of the role of $\mathrm{EZH} 2$ in cancer has been enhanced by the development of novel agents that inhibit EZH2 enzymatic activity, which are currently under evaluation in early phase clinical trials showing promising results.

\section{EVIDENCE CORRELATING EZH2 FUNCTION WITH CANCER}

\section{Solid tumors}

Increased EZH2 expression was initially demonstrated in prostate and breast cancer based on microarray studies which supported the hypothesis that the upregulation of this protein is associated with advanced stage and poor prognosis $[11,12]$. Subsequent studies showed that $\mathrm{EZH} 2$ is upregulated in various solid malignancies including renal cell carcinoma [13], lung [14, 15], hepatocellular [16], gastric [17], and pancreatic cancer [18]. Recent studies have highlighted the prognostic significance of EZH2 expression in a variety of solid cancers. Particularly, Wang et al in a meta-analysis study showed that EZH2 overexpression correlates with poor prognosis in patients with non-small cell lung cancer [19] while Bachmann et al in a prospective analysis of 700 cancer patients demonstrated that EZH2 is a marker of increased aggressiveness in patients with melanoma and endometrial cancer consistently with the previous findings in patients with breast and prostate cancer $[19,20]$. In the later study the authors found that EZH2 expression was strongly associated with loss of the cell cycle suppressor protein p16 in melanomas and endometrial carcinomas and increased expression in cyclin D1 in melanomas [20] connecting their findings with uncontrolled cell cycle in cancer cells overexpressing EZH2. EZH2 expression in colorectal cancer was reported to positively associate with TNM stage and lymph node metastasis [21] while another study evaluating the role of EZH2 expression in gastrointestinal malignancies, found that its overexpression is correlated with poor prognosis in esophageal but not colorectal and gastric cancer [22]. Moreover, EZH2 has been strongly associated with advanced stage and poor prognosis in squamous cell malignancies including cervical cancer [23], esophageal squamous cell carcinoma [24] and head and neck cancer [25]. Particularly, EZH2 promotes the epithelial to mesenchymal transformation (EMT) in head and neck carcinomas and decreases the sensitivity to cisplatin-based chemotherapy [25].

\section{HEMATOLOGIC MALIGNANCIES}

\section{Leukemia}

As opposed to solid tumors where EZH2 overexpression is clearly associated with disease progression and poor prognosis, data are not so clear in hematologic malignancies. Both overexpression [26] and loss-of-function mutations [27, 28] have been detected in myelodysplastic syndrome (MDS) and acute myeloid leukemia (AML) suggesting that $\mathrm{EZH} 2$ can function as tumor suppression and as an oncogene in myeloid malignancies. Tanaka et al proposed that EZH2 reinforces the differentiation blockage maintaining the self-renewal capacity of leukemic cells in AML [29]. Recent data suggest that EZH2 loss is more strongly associated with myelodysplastic syndromes, particularly, chronic myelomonocytic leukemia. It has been shown that EZH2 loss promotes the development of MDS in a RUNX1S21fs mutant model but inhibits the transformation to AML [30]. The authors suggested that despite the compromised proliferative capacity in the setting of EZH2 loss, induction of cytokine production in the tumor microenvironment might lead to expansion of the dysplastic myeloid clones while upregulation of EZH2 can promote progression to AML [30]. Similarly, Muto et al supported that deletion of EZH2 was sufficient to induce MDS/Myeloproliferative neoplasm (MDS/MPN) in transgenic mice [31], whereas Soverini et al reported loss-of-function mutations of EZH2 gene in chronic myeloid leukemia [32] further supporting the hypothesis that EZH2 inactivation may be implicated in chronic myeloid dysplasia and hyperplasia. On the contrary, EZH2 is frequently overexpressed in AML with complex phenotype [33], whereas EZH2 deletion decreases proliferation and promotes apoptosis in MLLAF9 transformed cells, and delays the progression of AML in transgenic mice [29]. Similarly, increased EZH2 expression is associated with extramedullary infiltration in AML and activation of ERK/c-Myc/MMP-2 and E-cadherin signaling [34].

\section{Non-Hodgkin Lymphomas}

EZH2 seems to have an active role in lymphoid malignancies since EZH2 gain-of-function mutations 
have been identified in germinal center B cell diffuse large-cell B cell lymphomas (DLBCL) and follicular lymphomas $[35,36]$. It has been determined that EZH2 methyltransferase activity is mandatory for the coordinated regulation of GC B cell differentiation, proliferation, and response to genotoxic damage imposed by activationinduced cytidine deaminase (AID). Conversely, enforced BLIMP1 repression, coupled to protection against AID mutagenesis, acceleration of S-phase entry, and enhanced BCL6 function, may represent the mechanism through which constitutively active EZH2 contributes to lymphomagenesis [37]. These results provide a basis for using EZH2 inhibitors [38-40] in combination with inducers of terminal B cell differentiation, such as IL-21 $[41,42]$ and genotoxic agents, for the treatment of GCderived DLBCL and follicular lymphoma.

Together these reports support the conclusion that EZH2 is dysregulated in a large spectrum of human malignancies and this event has prognostic significance. The mechanisms of EZH2 aberration and the molecular pathways involved in the regulation of EZH2 abundance and activity in human neoplasms together with the development of novel therapeutic opportunities to target $\mathrm{EZH} 2$ are under intense investigation.

\section{DEREGULATION OF EZH2 FUNCTION IN CANCER}

EZH2 expression and activity in cancer cells is altered at genetic, transcriptional, post-transcriptional and post-translational levels. The complexity of EZH2 regulation by multiple molecular pathways, most likely contributes to the variable implications of EZH2 aberrations in various types of cancer.

\section{EZH2 mutations}

Several recent studies have shown that heterozygous point mutations affecting tyrosine 641 (Y641) within the C-terminal catalytic SET domain of EZH2 have been identified in $22 \%$ of germinal center B cell diffuse large-cell B cell lymphomas (DLBCL) and in 7-12\% of follicular lymphomas $[35,36]$. This mutation mediates gain-of-function of EZH2 enzymatic activity leading to increased levels of trimethylated H3K27 (H3K27me3) [43] and resulting in down-regulation of Polycomb target genes such as TCF4, FOXP1, TCL1A, BIK, and RASSF6P in follicular lymphomas [44]. Other studies have identified additional EZH2 gain-of-function point mutations at the alanine 677 and 687 residues in non-Hodgkin's lymphomas, which are associated with increased H3K27 trimethylation $[45,46]$. Although the outcome of these gain-of-function mutations has documented a role of $\mathrm{EZH} 2$ as an oncogenic mediator, other findings suggest that EZH2 might function as a tumor suppressor because
$\mathrm{EZH} 2$ loss-of-function is associated with development of malignancy. Specifically, EZH2 inactivating deletion, frameshift, nonsense and missense mutations have been identified in myelodysplastic syndromes (MDS), myeloproliferative neoplasms (MPN) and MDS-MPN overlap disorders $[27,28]$. Consistently with these findings in patients, indicating a tumor-suppressive role of EZH2 in MDS, mice lacking Ezh2 have enhanced initiation and progression of Runx1-mutant MDS [30]. Loss-offunction mutations and deletions of $E Z H 2$ have also been identified in T cell acute lymphoblastic leukemia (T-ALL) [47]. Since EZH2 loss-of-function can drive oncogenesis of certain cancers, caution is required during therapeutic application of EZH2 inhibitors.

\section{Transcriptional regulation}

There is strong evidence that oncogenic signaling in a variety of human neoplasms leads to alteration of EZH2 transcriptional regulation promoting cancer cell proliferation and disease progression. The fusion protein EWS-FLI1 in Ewing's sarcoma cells promotes the expression of EZH2 and has been associated with endothelial/neuroectodermal differentiation in this type of tumor [48]. Similarly, RAS gain-of-function mutations have been associated with elevated EZH2 expression in various malignancies. In pancreatic cancer, RAS mutation promotes the expression of EZH2 through activation of the MEK-ERK-ELK1 signaling [49]. Activation of MEKERK signaling pathway has also been associated with EZH2 upregulation in triple negative and ERBB2 positive breast cancer [50]. It is believed that the phosphorylated ELK1 downstream of ERK binds to the EZH2 gene promoter activating its transcription $[10,51]$. It has been determined that different amino acid substitutions in oncogenic KRAS differently modulate EZH2 expression in lung adenocarcinoma showing that $\mathrm{KRAS}^{\mathrm{G} 12 \mathrm{C}}$ is associated with higher EZH2 expression [52]. This study also determined that different KRAS mutations can promote the expression of EZH2 through PI3K-AKT or MEKERK signaling in non-small cell lung cancer, a finding that allows for therapeutic combinations of pathway targeting agents, such as AKT and EZH2 inhibitors or MEK and EZH2 inhibitors, to achieve maximum therapeutic benefit in cancers which display joint aberration of these targets [52].

The Rb-E2F signaling has also been found to activate the expression of $\mathrm{EZH} 2$ through direct binding of $\mathrm{E} 2 \mathrm{~F}$ on the $E Z H 2$ promoter upon $\mathrm{Rb} / \mathrm{RB} 1$ phosphorylation in bladder and small cell lung cancer $[53,54]$. Hypoxia, which is a known driver of solid tumor progression, promotes EZH2 expression through HIF-1 $\alpha$ binding on the EZH2 promoter, inducing disease aggressiveness and progression [55]. Dong et al recently demonstrated that breast cancers overexpressing both $H I F-1 \alpha$ and $E Z H 2$ have poorer overall survival compared to cancers 
overexpressing one of these genes [56]. Importantly, in prostate cancer EZH2 is decreased by androgens, while androgen deprivation increases the expression of EZH2, which downregulates E-cadherin thereby promoting cell migration and cancer progression [57]. These findings provide better understanding of EZH2 regulation at the transcriptional level and justify the use of EZH2 inhibitors in combinational approaches for targeted cancer therapy.

\section{Post-transcriptional regulation}

The expression of EZH2 is also regulated by post-transcriptional mechanisms through micro-RNAs. Particularly, micro-RNAs (miRs) can bind to the EZH2 RNA transcript and modulate its stability, integrity and translation, directly affecting the levels of EZH2 protein. Multiple miRs such as miR-25, -26A, -101, -138 and -214 interact with the EZH2 3'UTR and promote its degradation $[51,58]$. Down-regulation of these miRs can lead to increased expression of EZH2 and may have implications in disease progression. Zhu et al recently found that miR138 , which is down-regulated in osteosarcoma, directly targets EZH2 transcript and can increase the sensitivity of osteosarcoma cells to cisplatin [59]. Other studies have identified a double-negative feedback loop between EZH2 and miR-26a in hepatocellular cancer, since miR26a, which directly targets EZH2 at a post-transcriptional level, is also abrogated by EZH2 overexpression [60]. Similarly, down-regulation of miR-101 in glioblastoma cells promotes their proliferation and invasion along with angiogenesis by increasing the EZH2-mediated overexpression of cytoplasmic polyadenylation elementbinding protein 1 (CPEB1) [61, 62]. These findings were further confirmed in astrocytic tumors in which it was determined that a network of interactions between EZH2 and miR-26a, $-27 \mathrm{a}$ and -498 is differentially expressed in low and high grade tumors. Detection of this EZH2 network may serve as a promising biomarker for tumor progression into higher grade [63].

Post-transcriptional regulation of $\mathrm{EZH} 2$ is also mediated by additional mechanisms. AKT1-mediated phosphorylation of EZH2 allows its interaction with androgen receptor promoting the expression of androgen receptor-target genes in the absence of androgens further supporting the involvement of EZH2 in the development and progression of castrate resistant prostate cancer [64]. Similarly, AKT1 phosphorylates EZH2 and induces the expression of STAT3 in glioblastoma with stem-like cells promoting tumorigenicity [65]. Cyclin-dependent kinases 1 and $2(\mathrm{CDK} 1 / 2)$ phosphorylate EZH2 at T350 increasing its recruitment at chromatin and positively affecting its stability and activity [66]. Phosphorylation of EZH2 by CKD1/2 at T492 disrupts the PRC2 assemblies and decreases EZH2 activity [67]. Moreover, CKD1 phosphorylation of EZH2 at T350 and T492 promotes EZH2 ubiquitinylation and degradation suggesting decreased methyltransferase activity [67]. While it is clear that CDK mediated EZH2 phosphorylation is critical for the maintenance of $\mathrm{H} 3 \mathrm{~K} 27 \mathrm{me} 3$ marks through the cell cycle, the role of this interaction in the fate and function of cancer cells warrants further investigation. Hussain et al demonstrated that exposure to tobacco smoke condensate leads to EZH2 binding on the promoter of the

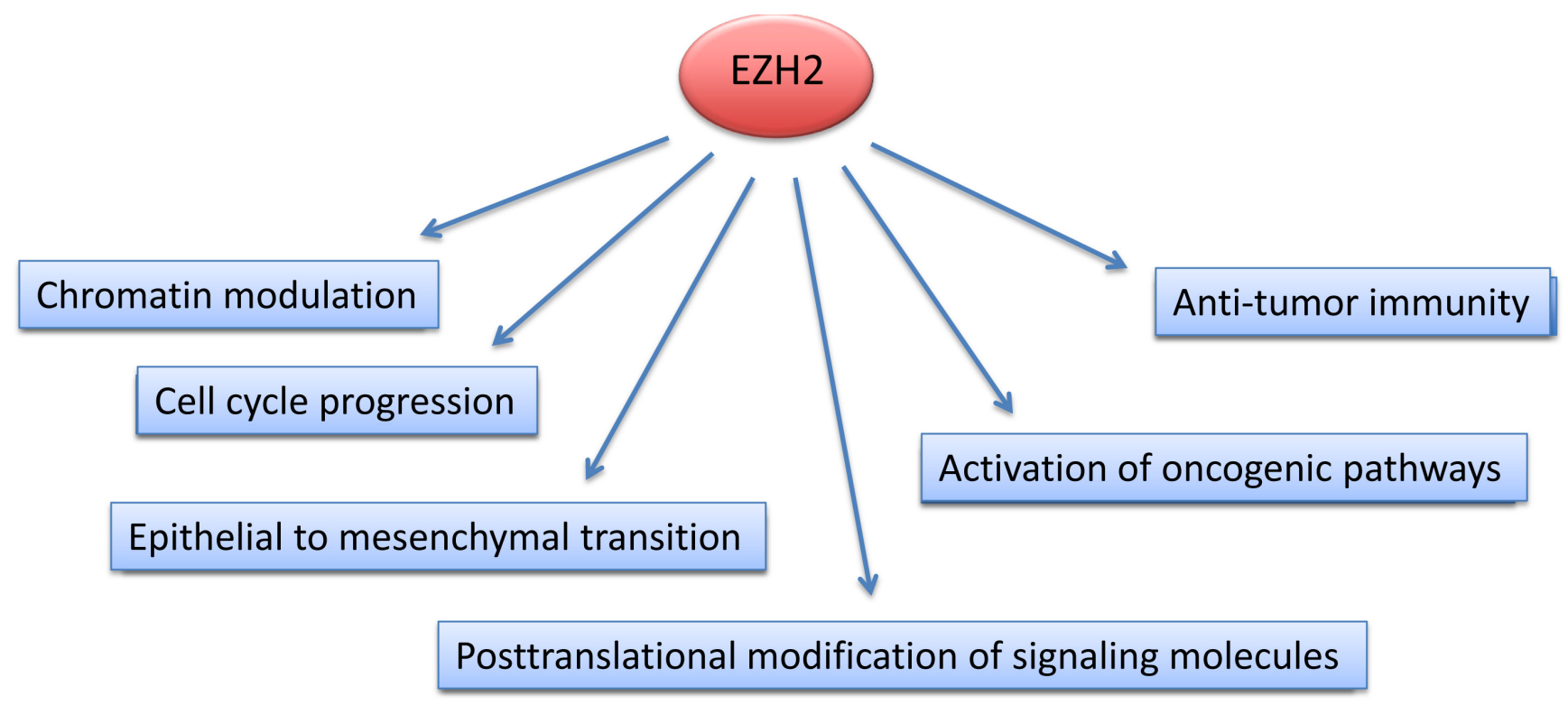

Figure 2: Mechanisms of EZH2-mediated implications in cancer. EZH2 expression and activity in cancer cells is altered at the genetic, epigenetic and post-translational levels. Such changes activate oncogenic genes and pathways thereby promoting tumorigenesis, and alter cell cycle progression and metastasis of cancer cells. EZH2-mediated alterations in cancer cells affect the recruitment of antitumor $\mathrm{T}$ cells in the tumor microenrvironment in response to tumor-immunotherapy. 
Wnt-antagonist, Dickorpf-1, inhibiting its transcription and activating oncogenic Wnt signaling in lung cancer cells [68]. These findings suggest a possible effect of an exogenous carcinogen through post-translational modification of EZH2. Taken together these studies strongly suggest that regulation of $\mathrm{EZH} 2$ at the posttranslational level might be of particular importance with regards to its activity and implication in cancer development and growth.

\section{CANCER CELL-INTRINSIC MECHANISMS OF EZH2-MEDIATED ONCOGENESIS}

Although the implication of EZH2 in the development and progression of malignancies has been extensively studied and well documented, the mechanism(s) involved remain uncertain. It is believed that EZH2 affects the pathogenesis of cancer by multiple different mechanisms as it is involved in a various cell intrinsic molecular pathways (Figure 2). Particularly, as part of PRC2, EZH2 can affect the expression of numerous target genes that are critical for the survival, proliferation and aggressiveness of cancer cells, via epigenetic mechanisms. In parallel, there is accumulating evidence that EZH2 is also involved in other oncogenic pathways that are not implicated in chromatin modulation. Moreover, EZH2 activity might have significant impact on immune-mediated tumor distraction in response to immunotherapy with checkpoint inhibitors.

\section{Chromatin modulation}

Since EZH2 suppresses the differentiation of normal embryonic stem cells by decreasing the expression of lineage specifying factors [69], it is not surprising that it is highly expressed in cancer stem cell (CSC) populations $[55,70]$ maintaining their survival and inhibiting their differentiation $[71,72]$. It is believed that EZH2 as part of the PRC2 suppresses cell specific transcriptional programs that mediate differentiation or apoptosis such as GSK-3 $\beta$ and p53 in cervical cancer [73], insulin-growth factor in lung cancer [74] p21 in ovarian cancer [75] and IKK $\alpha$ in nasopharyngeal carcinoma [76]. It should be noted though that EZH2 activity has also been associated with transcriptional activation of oncogenic signaling pathways associated with CSC survival and proliferation such as Wnt signaling in colorectal cancer $[73,77]$, NOTCH1 and TGF $\beta 1$ in prostate cancer [78], and STAT3 pathway in glioblastoma [65]. On the contrary, EZH2 inactivation correlates with increased growth and proliferation of stemcells and early-progenitor-cells in early T cell precursor acute lymphoblastic leukemia (ETP-ALL), which represents an aggressive type of acute lymphoblastic leukemia [79]. It is intriguing to speculate that EZH2, as a chromatin modulator and part of PRC2, is involved in cancer stem cell maintenance through alteration of transcriptional programs.

\section{Cell cycle progression and EMT}

One of the most important biologic roles of EZH2 in non-malignant cells is the regulation of cell cycle and it has been shown that EZH2 is required for the expression of genes implicated in E2F-driven cell proliferation. As mentioned above, E2F is involved in EZH2 deregulation in cancer and creates a double feedback between EZH2 and E2F-mediated cell proliferation and tumor progression. Moreover, down-regulation of EZH2 in glioblastoma leads to cell cycle arrest at the G0/G1 phase. This is associated with $\beta$-catenin/TCF4 and STAT3 downregulation, which can, in turn, suppress EZH2 expression representing a negative feedback loop that is deregulated in glioblastoma leading to uncontrolled cell cycle progression [80]. Thus, EZH2 significantly affects cell cycle progression in cancer cells.

It has been shown that PRC2 suppresses the Ink4a/ Arf pathway which is known to mediate DNA damage repair signaling that is critical for the development and progression of several malignancies [81]. Similarly, it has been shown that EZH2 down-regulates the expression of RAD51, which is also critical for the DNA damage repair especially under hypoxic conditions in solid tumors [55]. These alterations lead to accumulation of genomic aberrations such as RAF1 gene amplification and activation of RAF1-ERK- $\beta$-catenin signaling promoting the aggressiveness of breast tumors [55]. These conclusions highlight the critical role of EZH2 as part of PRC2 on DNA damage repair, which is impaired in various malignancies leading to accumulation of DNA damage and genomic instability.

There is strong evidence that EZH2 promotes epithelial to mesenchymal transition (EMT) by interacting with SNAIL1 and down-regulating the expression of E-cadherin [82, 83]. EZH2 also mediates the silencing of the Disabled Homolog2-Interacting Protein (DAB2IP), which has been implicated in the regulation of EMT and metastatic potential in colorectal cancer [84] and is a biomarker of good prognosis in medulloblastoma [85]. According to these findings in multiple malignancies EZH2 mediates the activation of EMT program, which is a known mechanism inducing tumor aggressiveness and metastasis.

\section{Activation of oncogenic pathways}

Recent studies have revealed that EZH2 upregulates oncogenic pathways acting independently of PRC2 at the transcriptional level. In prostate cancer cells, EZH2 interacts with androgen receptor (AR) independently of 
PRC2, and functions as a transcriptional co-activator inducing the expression of AR target genes [64]. Interestingly, in breast cancer EZH2 interacts with estrogen receptor (ER) and $\alpha$ and $\beta$-catenin promoting the expression of ER and Wnt signaling target genes [86]. It was also found that EZH2 interacts with RelA/ RelB complex co-regulating a subset of NF- $\kappa \mathrm{B}$ targets independently of PRC2, and increasing the aggressiveness of breast cancer cells [87]. EZH2 also activates Ras and $\mathrm{NF} \kappa \mathrm{B}$ signaling through down-regulating DAB2IP promoting prostate tumor development and metastasis [88]. These data suggest that EZH2 can act as a chromatin modulator independently of PRC2 inducing the expression of oncogenes involved in the development and progression of various cancers.

\section{Posttranslational modification of signaling molecules}

Apart from its role as a chromatin modulator or direct activator of oncogenic pathways, EZH2 can alter signaling pathways in cancer cells by posttranslational mechanisms that alter the properties of key signaling molecules, further supporting the complexity of EZH2 involvement in cancer biology. For example, EZH2 can methylate non-histone substrates such as STAT3 inducing the tumorigenicity in glioblastoma stem-like cells [65] and melanoma [89]. EZH2 can also methylate AR in prostate cancer promoting its chromatin binding and the up-regulation of AR downstream targets [64]. Similarly, EZH2 directly methylates talin, a critical component of the cell migration machinery and disrupts talin binding to F-actin thereby disrupting the cell-to-cell adhesion process in leukocytes [90]. Although such talin-related function
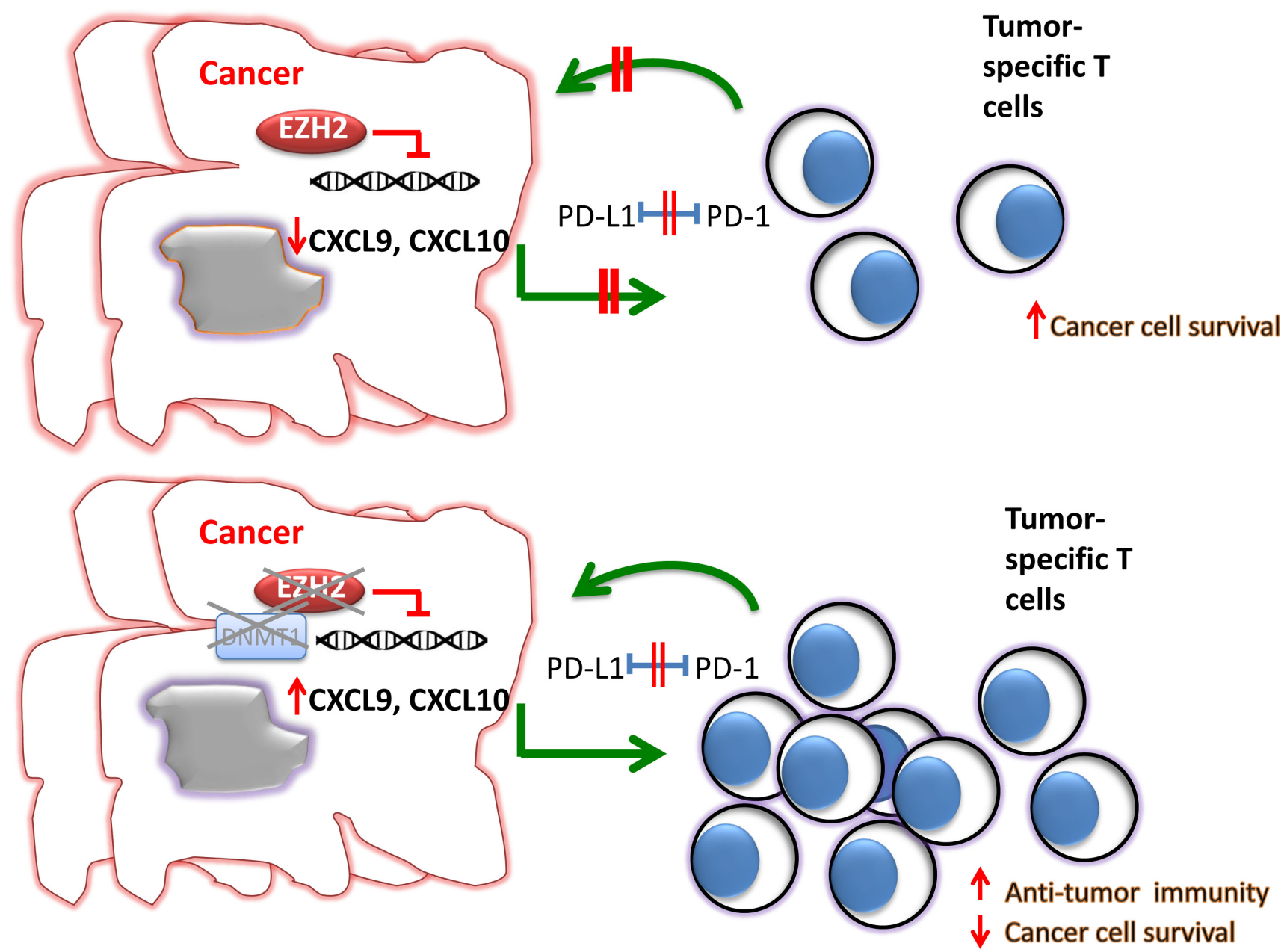

Figure 3: EZH2 expression and function in cancer cells alters the efficacy of tumor immunotherapy. A. Expression and activation of EZH2 in cancer cells inhibits the production of Th1 type chemokines such as CXCL9 and CXCL10, thereby compromising the trafficking of tumor-specific T cells, which mediate cytotoxic effects on cancer cells and promote anti-tumor function. B. Inhibition of EZH2 together with DNMT1 promotes T cell recruitment to the tumor site and enhances responses to blockade of the PD1: PD-L1 checkpoint. 
Table 1: EZH2 inhibitors: Mechanism and status of clinical development

\begin{tabular}{|c|c|c|c|}
\hline Compound & Mechanism & Status of development & References \\
\hline DNZep & $\begin{array}{l}\begin{array}{l}\text { Regulator of EZH2 } \\
\text { levels }\end{array} \\
\end{array}$ & Pre-clinical & {$[103,104]$} \\
\hline EGCG & $\begin{array}{l}\text { Regulator of EZH2 } \\
\text { levels }\end{array}$ & Pre-clinical & {$[105]$} \\
\hline PL3 & $\begin{array}{l}\text { Regulator of EZH2 } \\
\text { levels }\end{array}$ & Pre-clinical & {$[106]$} \\
\hline $\mathrm{CDF}$ & $\begin{array}{l}\text { Regulator of EZH2 } \\
\text { levels }\end{array}$ & Pre-clinical & {$[107]$} \\
\hline SAH-EZH2 & $\begin{array}{l}\text { Inhibitor of EZH2- } \\
\text { PRC2 interaction }\end{array}$ & Pre-clinical & {$[108]$} \\
\hline Astemizole & $\begin{array}{l}\text { Inhibitor of EZH2- } \\
\text { PRC2 interaction }\end{array}$ & Pre-clinical & [109] \\
\hline CPI-1205 & $\begin{array}{l}\text { Inhibitor of EZH2- } \\
\text { PRC2 interaction }\end{array}$ & $\begin{array}{l}\text { Phase I (ClinicalTrials.gov } \\
\text { Identifier NCT02395601) }\end{array}$ & \\
\hline EPZ005687 & $\begin{array}{l}\text { Competitive } \quad \text { EZH2 } \\
\text { inhibitor }\end{array}$ & Pre-clinical & {$[10,38]$} \\
\hline GSK126 & $\begin{array}{l}\text { Competitive } \quad \mathrm{EZH} 2 \\
\text { inhibitor }\end{array}$ & $\begin{array}{l}\text { Phase I clinical trial } \\
\text { (ClinicalTrials.gov } \\
\text { Identifier NCT02082977) }\end{array}$ & {$[39,110-113]$} \\
\hline EPZ011989 & $\begin{array}{ll}\text { Competitive } & \text { EZH2 } \\
\text { inhibitor } & \\
\end{array}$ & Pre-clinical & [114] \\
\hline ZLD1039 & $\begin{array}{l}\text { Competitive } \quad \text { EZH2 } \\
\text { inhibitor }\end{array}$ & Pre-clinical & {$[115]$} \\
\hline EPZ-6438 & $\begin{array}{l}\text { Competitive } \quad \mathrm{EZH} 2 \\
\text { inhibitor }\end{array}$ & $\begin{array}{l}\text { Phase II clinical trials } \\
\text { (ClinicalTrials.gov } \\
\text { Identifier NCT01897571) }\end{array}$ & {$[10,116]$} \\
\hline
\end{tabular}

of EZH2 has not been identified in cancer cells, it would be important to investigate whether such mechanism mediated by EZH2 might affect cancer cell adhesion and migration and might be critical for the regulation of invasion and metastasis.

\section{INVOLVEMENT OF EZH2 IN TUMOR IMMUNITY}

As mentioned above, EZH2 has been studied extensively as a promoter of cancer progression through the induction of cell cycle and inhibition of cancer cell differentiation. However, recent work revealed that EZH2 might have a novel and important involvement in cancer via a mechanism that alters the immunogenicity of the tumor microenvironment (Figure 3). In a recent study, Peng et al, using a mouse model of ovarian cancer, showed that epigenetic alterations of cancer cells by inhibition of EZH2 and DNA methyltransferase 1 (DNMT1) resulted in increased expression of the Th1-type chemokines CXCL9 and CXCL10 in cancer cells, leading to increased trafficking of effector $\mathrm{T}$ cells to the tumor site and decreased tumor volume [91]. Conversely, increased expression of EZH2 and DNMT1 in ovarian tumors was associated with decreased infiltration of CD8 $+\mathrm{T}$ cells and poor prognosis. Furthermore, treatment of ovarian tumors with EZH2 and DNMT1 inhibitors increased the efficacy of tumor-associated antigen-specific CD8+ $\mathrm{T}$ cells in response to inhibition of the PD-1: PD-L1 checkpoint [91]. A similar effect of EZH2 was observed in colorectal cancer, where targeting EZH2 in cancer cells also augmented the expression of CXCL9 and CXCL10 chemokines, affecting the infiltration of the tumor by effector T cells [92].

A recent study by Yin et al has provided insight to the contribution of epigenetic mechanisms in the development of $\mathrm{NK}$ cells and suggested that EZH2 inhibitors might inhibit tumor growth directly and indirectly through mobilization of NK cells. Ezh2-null hematopoietic stem and progenitor cells (HSPCs) or HSPCs treated with Ezh2 inhibitors gave rise to increased NK precursors and mature progeny that display enhanced cytotoxicity against tumor cells and these functional outcomes were associated with up-regulation of IL15R (CD122) and the NKG2D-activating receptor [93]. Because EZH2 is overexpressed in several cancers, it has been considered that can function as a tumor-associated antigen (TAA). Indeed, identification of an immunogenic epitope of EZH2 recognized by CD4 T-cell in lung cancer, could serve as a potent immunogenic target inducing both CD4 and CD8 T-cell anti-tumor responses [94].

There is accumulating evidence that EZH2 has a direct role in $\mathrm{T}$ cell differentiation and function. EZH2 expression in naïve T cells inhibits Th1 and Th2 differentiation but is critical for survival, proliferation 
and efficacy of effector CD4+ and CD8+ T cells in vivo [95]. These observations suggest that while inhibition of $\mathrm{EZH} 2$ in cancer cells can promote anti-tumor immunity by enhancing recruitment of $\mathrm{T}$ effector cells in the tumor microenvironment [91, 92], inhibition of EZH2 on T cells may suppress survival, expansion and efficacy of such tumor-specific effectors thereby inducing the opposite effect. Indeed, Zhao et al determined that via competitive glucose consumption, ovarian cancer can induce expression of specific micro-RNAs in CD4+ and $\mathrm{CD} 8+\mathrm{T}$ cells of the tumor microenvironment, which suppress the expression of EZH2 and decrease their survival and immune function [96]. Moreover, the authors demonstrated that down-regulation or inhibition of EZH2 in tumor-specific T cells increases the tumor burden and the metastatic potential in mouse models of ovarian cancer and melanoma, respectively. Importantly, the percentage of $\mathrm{EZH}_{2}{ }^{+} \mathrm{CD}^{+} \mathrm{T}$ cells in the ovarian cancer tissues is a stronger predictor of overall and progression-free survival compared to the percentage of $\mathrm{CD}^{+} \mathrm{T}$ cells. These data support the hypothesis that EZH2 has a key role for the function of tumor-specific effector $\mathrm{T}$ cells, while cancer can evade tumor surveillance by targeting T-cell specific expression of EZH2 in the tumor microenvironment.

EZH2 also has an important role in the function of $\mathrm{T}$ regulatory cells (Tregs), which are also involved in immune homeostasis and anti-tumor immunity. It has been recently recognized that EZH2 is critical for the recruitment and homing of activated Tregs at the sites of inflammation [97]. Consistent with these findings, Yang et al determined that EZH2-deficient Tregs failed to protect mice from the development of autoimmunity in a model of naïve $\mathrm{T}$ cell-mediated colitis [95]. It has been documented that tumor cells can induce Tregs in the tumor microenvironment by secreting soluble factors such as TGF-beta, VEGF and GM-CSF, which convert tissue infiltrating CD4+ T cells to Foxp3+ Treg [98, 99]. Because of the unequivocal negative impact of Treg localization in the tumor microenvironment on anti-tumor immunity [100-103] the regulation of EZH2 expression in Tregs in tumor microenvironment is of particular interest for understanding and modulating anti-tumor immunity.

These results support the hypothesis that the tumorigenic effects of epigenetic modifications in cancer cells may be mediated by alteration of anti-tumor $\mathrm{T}$ cell function in the tumor microenvironment. Importantly, the functions of EZH2 in T effector and Treg cells appear to mediate distinct and opposing roles, in anti-tumor immunity. Thus, the use of EZH2 inhibitors with the goal to inhibit tumor growth will likely simultaneously alter the functions of immune cells in the tumor microenvironment. Although EZH2 inhibitors would provide an attractive treatment strategy in cancers with high EZH2 expression and activation, such approaches might have unpredictable effects on anti-tumor immunity.

\section{TARGETING OF EZH2 FOR CANCER THERAPY}

Given the extensive implication of EZH2 on cancer development and progression, the introduction of EZH2 inhibitors has been an area of intense pre-clinical and clinical investigation. 3-deazaadenosine A (DZNep) is a non-specific EZH2 inhibitor which decreases its protein levels and removes the H3K27me3 marks from the chromatin and shows significant anti-tumor effect in various malignancies with reported efficacy but also toxicity in animal models $[104,105]$. Numerous other agents such as ECGC, PL3 and CDF act similarly to DZNep decreasing the protein levels of EZH2 but due to their limited specificity, toxicity is the main concern and this is probably the reason why those agents have not been evaluated in clinical trials yet [106-108].

Recent studies have demonstrated that inhibition of the interaction between EZH2 and other components of the PRC2 complex may be more a specific approach with efficacy against various neoplastic diseases and decreased toxicity. Stabilized alpha-helix of EZH2 (SAH-EZH2) peptides disrupt the EZH2/EED interaction and decrease the EZH2 levels leading to decreased methyltransferase activity leading to growth arrest and differentiation of MLL-AF9 leukemic cells [109]. Similarly, Astemizole is a small molecule inhibitor of EZH2/EED interaction which destabilizes PRC2 complex decreasing the proliferation of lymphoma cells [110]. Finally, CPI-1205 selectively inhibits the interaction of EZH2 with PRC2 complex and is currently evaluated in a phase 1 clinical trial in patients with B-cell lymphomas (NCT02395601).

Currently, research is more focused on agents acting as competitive inhibitors of EZH2 binding to the wild type or the mutant protein. EPZ0005687 is a selective EZH2 inhibitor that can bind to the wild-type and the Y641 mutant EZH2. EPZ0005687 has shown efficacy in inhibiting the H3K27me3 activity in lymphoma, breast and prostate cancer cells $[10,38]$. GSK126 is another EZH2 inhibitor, which appears to be effective against wild type and mutant EZH2 [111]. Particularly, it was demonstrated that GSK126 can effectively inhibit the proliferation of EZH2 mutant DLBCL both in vitro and in xenograft mouse models [39]. Similarly, it was found that inhibition of EZH2 with GSK126 induces apoptosis in multiple castrate resistant prostate cancer cell lines [112]. In addition, GSK126 can target mutant EZH2 effectively in melanoma cells by de-repressing tumor suppressor genes and subsequently inhibiting tumor growth [113]. Finally, it was recently reported that GSK126 can inhibit cell migration and angiogenesis in models of gastric and lung cancer [114] further supporting that this compound effectively suppresses the EZH2-mediated oncogenic pathways may be a promising agent in targeted therapeutics in cancer. Table 1 summarizes the currently available EZH2 inhibitors, their mechanism and the status 
of their clinical development.

Last year, the development of EPZ011989, a selective and orally available EZH2 inhibitor, was reported and was shown to have significant activity in a mouse xenograft model of B cell lymphoma [115]. Another more recent study introduced ZLD1039, a highly selective, potent and orally available agent decreasing the H3K27 methylation leading to up-regulation of silenced tumor suppressor genes in breast cancer [116]. This compound can suppress the tumor growth but also inhibit metastasis in a mouse breast cancer xenograft model [116]. EPZ6438, another orally available EZH2 inhibitor, decreases the levels of H3K27me3 in a dose-dependent manner leading to significant reduction of tumor growth in non-Hodgkin lymphoma expressing EZH2 mutant [117]. EPZ6438 is currently under evaluation in a phase $1 / 2$ clinical trial in patients with B cell lymphomas and advanced solid tumors (NCT01897571) with encouraging preliminary findings [10]. This compound is being evaluated in a phase 1 clinical trial for pediatric patients (NCT02601937) and in a phase 2 clinical trial for adults (NCT02601950) evaluating the efficacy and safety for patients with relapsed rhabdoid tumors, synovial sarcomas, renal medullary carcinoma and epithelioid sarcoma.

Numerous recent studies have concluded that EZH2 inhibition increases the sensitivity of cancer cells to radiation and traditional chemotherapy. Alimova et al have shown that EZH2 inhibition sensitizes atypical teratoid/rhabdoid tumor cells to radiation [118] while Xia et al demonstrated that down-regulation of EZH2 by siRNA enhances the anti-tumor effect of ionizing radiation in non-small cell lung cancer [119]. EZH2 inhibition in EGFR and BRG1 mutant lung cancer leads to accumulation of cancer cells in S phase, anaphase bridging and subsequently to increased sensitivity to Topoisomerase II inhibitors [120]. Inhibition of EZH2 in B cell lymphomas induces p53-mediated apoptosis under DNA damage accumulation, re-sensitizing these cells to etoposide [120,121]. Combination of the EZH2 inhibitor GSK126 with etoposide in prostate cancer led to accumulation of DNA damage and increased the apoptotic rates compared to each monotherapy [122]. Recently, $\mathrm{Neo}$ et al identified c-Rel as a positive regulator of EZH2 expression in activated primary murine lymphocytes and human malignant lymphoid cells and treatment with the c-Rel inhibitor pentoxifylline (PTX) not only reduced EZH2 expression but also reduced the survival of human leukemia/lymphoma cell lines by enhancing their sensitivity to the EZH2-specific inhibitor, GSK126 [123]. These studies provide strong evidence that the addition of EZH2 inhibitors can increase the sensitivity of cancer cells to traditional therapeutic approaches, small molecule inhibitors or radiation therapy by increasing the levels of DNA damage and genomic instability, and further suggest the promising potential of EZH2-targeting compounds in in cancer therapeutics.

\section{EZH2 POLYMORPHISMS AND IMPLICATIONS IN CANCER BIOLOGY AND IMMUNOTHERAPY}

Several EZH2 gene variations have been proposed to influence the risk of carcinogenesis, bearing either a predictive or a prognostic role. According to a recent study, the "CC" genotype of rs6950683 and rs3757441 is associated with decreased risk of oral squamous cell carcinoma development in Taiwan population, compared to carriers of the wild-type gene [124]. Additionally, EZH2 promoter hypermethylation has been observed in rs6950683 CC genotype in patients with oral squamous cell carcinoma (OSCC) [124]. Another study in Taiwan population suggested that the risk of urothelial carcinoma development is decreased by the presence of at least one $\mathrm{C}$ allele on the rs6950683 SNP, but the presence of at least one $\mathrm{G}$ is more common in urothelial carcinoma patients with less invasive tumor compared to patients without a $\mathrm{G}$ allele [125]. rs6950683 is also associated with liver carcinoma in Taiwan population, since the presence of at least a $\mathrm{C}$ at rs6950683 and rs3757441 decreases the risk of developing hepatocellular carcinoma but the same genotype simultaneously increases the risk of lymph-nodemetastasis in hepatocellular carcinoma patients [126]. In Han Chinese population, 148505302C $>\mathrm{T}$ polymorphism seems to have a protective action against colorectal carcinoma, in contrast to 626-394T $>\mathrm{C}$ which presents an increased risk [127]. 626-394T $>\mathrm{C}$ is also associated with increased risk of esophageal squamous cell carcinoma in the same population [128]. Finally, reduced risk of gastric cancer is associated with rs 2072407 , rs 734005 , and rs734004, while rs 12670401 and rs6464926 contribute to increased risk of gastric cancer occurrence [129].

According to Paolicchi et al, longer overall survival in cholangiocarcinoma patients is associated with rs887569 TT genotype compared to cholangiocarcinoma patients carrying CT or CC genotype [130]. In metastatic colorectal cancer patients treated with first-line 5-fluorouracil, folinic acid, irinotecan (FOLFIRI) and bevacizumab, shorter overall survival and progressionfree survival was correlated with expression of rs 3757441 $\mathrm{C} / \mathrm{C}$ compared to rs3757441 $\mathrm{T} / \mathrm{T}$ or $\mathrm{C} / \mathrm{T}$ patients [131]. Moreover, EZH2 expression is higher in rs 3757441 $\mathrm{C} / \mathrm{C}$ genotype patients [131]. In addition, the risk of hepatocellular carcinoma is reduced in GC or GC rs2302427 genotypes carriers [132]. Finally, significantly reduced risk of lung cancer development is associated by rs6950683 and rs3757441 [133].

\section{CONCLUSIONS}

EZH2 is a methyltransferase and catalytic component of the PRC2, and mediates methylation of $\mathrm{H} 3 \mathrm{~K} 27$. Accumulating evidence from in vitro and in vivo 
models together with studies in human cancers strongly suggest that EZH2 is involved in the development and progression of several human malignancies. EZH2 activity is up-regulated in cancer due to gain-offunction mutations, down-regulation of its suppressors, amplification of gene expression or increase of protein abundance by oncogenic pathways such as PI3K-AKT and MEK-ERK, post-transcriptional and post-translational modifications. EZH2 mediates its functions as part of PRC2 but also as an independent chromatin modulator. EZH2 downregulates the expression of tumor suppressor genes such as GSK-3 $\beta$, RAD51 and P53 and upregulates oncogenes such as STAT3 and NOTCH1, promoting cancer cell survival and proliferation, increasing genomic instability and inhibiting cell differentiation. EZH2 has been particularly associated with the expansion of cancer stem cells, cell cycle progression, accumulation of DNA damage through inhibition of DNA damage repair and epithelial to mesenchymal transition. Targeted compounds inhibiting EZH2 have been introduced in cancer therapeutics with promising results in preclinical studies as monotherapies or in combination with traditional chemotherapy and are currently under evaluation in phase 1 and 2 clinical trials. EZH2 is critical for survival, proliferation and efficacy of effector CD4+ and CD8+ T cells but also promotes recruitment of Treg cells in sites of inflammation. Inhibition of EZH2 and DNA methyltransferase 1 (DNMT1) resulted in increased expression of the Th1-type chemokines in cancer cells, leading to increased trafficking of effector $\mathrm{T}$ cells to the tumor site and decreased tumor volume. As EZH2 inhibitors are currently being tested in several clinical trials as anti-cancer drugs, novel important observations are anticipated to emerge about how these compounds also affect anti-tumor immune function. In the era of cancer immunotherapy, therapeutic targeting EZH2 will pose new challenges.

\section{ACKNOWLEDGMENTS}

This work was supported by by NIH grants CA183605, CA183605S1 and AI098129-01 and by the DoD grant PC140571.

\section{CONFLICTS OF INTEREST}

There is no conflict of interest.

\section{REFERENCES}

1. Lewis EB. A gene complex controlling segmentation in Drosophila. Nature. 1978; 276(5688):565-570.

2. Margueron R and Reinberg D. The Polycomb complex PRC2 and its mark in life. Nature. 2011; 469(7330):343349.
3. Cao R, Wang L, Wang H, Xia L, Erdjument-Bromage H, Tempst P, Jones RS and Zhang Y. Role of histone H3 lysine 27 methylation in Polycomb-group silencing. Science (New York, NY). 2002; 298(5595):1039-1043.

4. $\mathrm{Ku} \mathrm{M}$, Koche RP, Rheinbay E, Mendenhall EM, Endoh M, Mikkelsen TS, Presser A, Nusbaum C, Xie X, Chi AS, Adli M, Kasif S, Ptaszek LM, et al. Genomewide analysis of PRC1 and PRC2 occupancy identifies two classes of bivalent domains. PLoS genetics. 2008; 4(10):e1000242.

5. Gui Y, Guo G, Huang Y, Hu X, Tang A, Gao S, Wu R, Chen C, Li X, Zhou L, He M, Li Z, Sun X, et al. Frequent mutations of chromatin remodeling genes in transitional cell carcinoma of the bladder. Nature genetics. 2011; 43(9):875878.

6. Ho AS, Kannan K, Roy DM, Morris LG, Ganly I, Katabi N, Ramaswami D, Walsh LA, Eng S, Huse JT, Zhang J, Dolgalev I, Huberman K, et al. The mutational landscape of adenoid cystic carcinoma. Nature genetics. 2013; 45(7):791-798.

7. Huether R, Dong L, Chen X, Wu G, Parker M, Wei L, Ma J, Edmonson MN, Hedlund EK, Rusch MC, Shurtleff SA, Mulder HL, Boggs K, et al. The landscape of somatic mutations in epigenetic regulators across 1,000 paediatric cancer genomes. Nature communications. 2014; 5:3630.

8. Orkin $\mathrm{SH}$ and Hochedlinger K. Chromatin connections to pluripotency and cellular reprogramming. Cell. 2011; 145(6):835-850.

9. $\mathrm{Wu} \mathrm{L}$, Murat P, Matak-Vinkovic D, Murrell A and Balasubramanian S. Binding interactions between long noncoding RNA HOTAIR and PRC2 proteins. Biochemistry. 2013; 52(52):9519-9527.

10. Kim KH and Roberts CW. Targeting EZH2 in cancer. Nature medicine. 2016; 22(2):128-134.

11. Varambally S, Dhanasekaran SM, Zhou M, Barrette TR, Kumar-Sinha C, Sanda MG, Ghosh D, Pienta KJ, Sewalt RG, Otte AP, Rubin MA and Chinnaiyan AM. The polycomb group protein EZH2 is involved in progression of prostate cancer. Nature. 2002; 419(6907):624-629.

12. Kleer CG, Cao Q, Varambally S, Shen R, Ota I, Tomlins SA, Ghosh D, Sewalt RG, Otte AP, Hayes DF, Sabel MS, Livant D, Weiss SJ, et al. EZH2 is a marker of aggressive breast cancer and promotes neoplastic transformation of breast epithelial cells. Proceedings of the National Academy of Sciences of the United States of America. 2003; 100(20):11606-11611.

13. Lee HW and Choe M. Expression of EZH2 in renal cell carcinoma as a novel prognostic marker. Pathology international. 2012; 62(11):735-741.

14. Behrens C, Solis LM, Lin H, Yuan P, Tang X, Kadara H, Riquelme E, Galindo H, Moran CA, Kalhor N, Swisher SG, Simon GR, Stewart DJ, et al. EZH2 protein expression associates with the early pathogenesis, tumor progression, and prognosis of non-small cell lung carcinoma. Clinical cancer research. 2013; 19(23):6556-6565. 
15. Sato $\mathrm{T}$, Kaneda A, Tsuji S, Isagawa $\mathrm{T}$, Yamamoto $\mathrm{S}$, Fujita T, Yamanaka R, Tanaka Y, Nukiwa T, Marquez VE, Ishikawa $\mathrm{Y}$, Ichinose $\mathrm{M}$ and Aburatani H. PRC2 overexpression and PRC2-target gene repression relating to poorer prognosis in small cell lung cancer. Scientific reports. 2013; 3:1911.

16. Kondo Y, Shen L, Suzuki S, Kurokawa T, Masuko K, Tanaka Y, Kato H, Mizuno Y, Yokoe M, Sugauchi F, Hirashima N, Orito E, Osada $\mathrm{H}$, et al. Alterations of DNA methylation and histone modifications contribute to gene silencing in hepatocellular carcinomas. Hepatology research. 2007; 37(11):974-983.

17. Matsukawa Y, Semba S, Kato H, Ito A, Yanagihara K and Yokozaki H. Expression of the enhancer of zeste homolog 2 is correlated with poor prognosis in human gastric cancer. Cancer science. 2006; 97(6):484-491.

18. Ougolkov AV, Bilim VN and Billadeau DD. Regulation of pancreatic tumor cell proliferation and chemoresistance by the histone methyltransferase enhancer of zeste homologue 2. Clinical cancer research. 2008; 14(21):6790-6796.

19. Wang X, Zhao H, Lv L, Bao L, Wang X and Han S. Prognostic Significance of EZH2 Expression in Non-Small Cell Lung Cancer: A Meta-analysis. Scientific reports. 2016; 6:19239.

20. Bachmann IM, Halvorsen OJ, Collett K, Stefansson IM, Straume O, Haukaas SA, Salvesen HB, Otte AP and Akslen LA. EZH2 expression is associated with high proliferation rate and aggressive tumor subgroups in cutaneous melanoma and cancers of the endometrium, prostate, and breast. Journal of clinical oncology. 2006; 24(2):268-273.

21. Song-Bing H, Hao Z, Jian Z, Guo-Qiang Z, Tuo H, DaiWei W, Wen G, Lin G, Yi Z, Xiao-Feng X, Li-Feng Z, Min F, Shui-Qing H, et al. Inhibition of EZH2 expression is associated with the proliferation, apoptosis and migration of SW620 colorectal cancer cells in vitro. Experimental biology and medicine (Maywood, NJ). 2015; 240(4):546555.

22. Wang W, Wang F, Zong G, Liu R, Zhang Y, Luan Y, Xu $\mathrm{L}$ and Xuan J. Prognostic significance of EZH2 expression in patients with digestive cancers: a meta-analysis. International journal of clinical and experimental medicine. 2015; 8(9):16043-16049.

23. Jin $M$, Yang Z, Ye W, Yu X and Hua X. Prognostic significance of histone methyltransferase enhancer of zeste homolog 2 in patients with cervical squamous cell carcinoma. Oncology letters. 2015; 10(2):857-862.

24. Liu F, Gu L, Cao Y, Fan X, Zhang F and Sang M. Aberrant overexpression of EZH2 and $\mathrm{H} 3 \mathrm{~K} 27 \mathrm{me} 3$ serves as poor prognostic biomarker for esophageal squamous cell carcinoma patients. Biomarkers. 2016; 21(1):80-90.

25. Chang JW, Gwak SY, Shim GA, Liu L, Lim YC, Kim JM, Jung MG and Koo BS. EZH2 is associated with poor prognosis in head-and-neck squamous cell carcinoma via regulating the epithelial-to-mesenchymal transition and chemosensitivity. Oral oncology. 2016; 52:66-74.
26. Xu F, Li X, Wu L, Zhang Q, Yang R, Yang Y, Zhang Z, He Q and Chang C. Overexpression of the EZH2, RING1 and BMI1 genes is common in myelodysplastic syndromes: relation to adverse epigenetic alteration and poor prognostic scoring. Annals of hematology. 2011; 90(6):643-653.

27. Ernst T, Chase AJ, Score J, Hidalgo-Curtis CE, Bryant C, Jones AV, Waghorn K, Zoi K, Ross FM, Reiter A, Hochhaus A, Drexler HG, Duncombe A, et al. Inactivating mutations of the histone methyltransferase gene EZH2 in myeloid disorders. Nature genetics. 2010; 42(8):722-726.

28. Nikoloski G, Langemeijer SM, Kuiper RP, Knops R, Massop M, Tonnissen ER, van der Heijden A, Scheele $\mathrm{TN}$, Vandenberghe $\mathrm{P}$, de Witte $\mathrm{T}$, van der Reijden BA and Jansen JH. Somatic mutations of the histone methyltransferase gene EZH2 in myelodysplastic syndromes. Nature genetics. 2010; 42(8):665-667.

29. Tanaka S, Miyagi S, Sashida G, Chiba T, Yuan J, Mochizuki-Kashio M, Suzuki Y, Sugano S, Nakaseko C, Yokote K, Koseki H and Iwama A. Ezh2 augments leukemogenicity by reinforcing differentiation blockage in acute myeloid leukemia. Blood. 2012; 120(5):1107-1117.

30. Sashida G, Harada H, Matsui H, Oshima M, Yui M, Harada Y, Tanaka S, Mochizuki-Kashio M, Wang C, Saraya A, Muto T, Hayashi Y, Suzuki K, et al. Ezh2 loss promotes development of myelodysplastic syndrome but attenuates its predisposition to leukaemic transformation. Nature communications. 2014; 5:4177.

31. Muto T, Sashida G, Oshima M, Wendt GR, MochizukiKashio M, Nagata Y, Sanada M, Miyagi S, Saraya A, Kamio A, Nagae G, Nakaseko C, Yokote K, et al. Concurrent loss of Ezh2 and Tet2 cooperates in the pathogenesis of myelodysplastic disorders. The Journal of experimental medicine. 2013; 210(12):2627-2639.

32. Soverini S, de Benedittis C, Mancini M and Martinelli G. Mutations in the BCR-ABL1 Kinase Domain and Elsewhere in Chronic Myeloid Leukemia. Clinical lymphoma, myeloma \& leukemia. 2015; 15 Suppl:S120-128.

33. Grubach L, Juhl-Christensen C, Rethmeier A, Olesen LH, Aggerholm A, Hokland P and Ostergaard M. Gene expression profiling of Polycomb, Hox and Meis genes in patients with acute myeloid leukaemia. European journal of haematology. 2008; 81(2):112-122.

34. Zhu Q, Zhang L, Li X, Chen F, Jiang L, Yu G, Wang Z, Yin C, Jiang X, Zhong Q, Zhou H, Ding B, Wang C, et al. Higher EZH2 expression is associated with extramedullary infiltration in acute myeloid leukemia. Tumour biology. 2016.

35. Morin RD, Johnson NA, Severson TM, Mungall AJ, An J, Goya R, Paul JE, Boyle M, Woolcock BW, Kuchenbauer F, Yap D, Humphries RK, Griffith OL, et al. Somatic mutations altering EZH2 (Tyr641) in follicular and diffuse large B-cell lymphomas of germinal-center origin. Nature genetics. 2010; 42(2):181-185.

36. Bodor C, O'Riain C, Wrench D, Matthews J, Iyengar S, Tayyib H, Calaminici M, Clear A, Iqbal S, Quentmeier 
H, Drexler HG, Montoto S, Lister AT, et al. EZH2 Y641 mutations in follicular lymphoma. Leukemia. 2011; 25(4):726-729.

37. Caganova M, Carrisi C, Varano G, Mainoldi F, Zanardi F, Germain PL, George L, Alberghini F, Ferrarini L, Talukder AK, Ponzoni M, Testa G, Nojima T, et al. Germinal center dysregulation by histone methyltransferase EZH2 promotes lymphomagenesis. The Journal of clinical investigation. 2013; 123(12):5009-5022.

38. Knutson SK, Wigle TJ, Warholic NM, Sneeringer CJ, Allain CJ, Klaus CR, Sacks JD, Raimondi A, Majer CR, Song J, Scott MP, Jin L, Smith JJ, et al. A selective inhibitor of EZH2 blocks H3K27 methylation and kills mutant lymphoma cells. Nature chemical biology. 2012; 8(11):890-896.

39. McCabe MT, Ott HM, Ganji G, Korenchuk S, Thompson C, Van Aller GS, Liu Y, Graves AP, Della Pietra A, 3rd, Diaz E, LaFrance LV, Mellinger M, Duquenne C, et al. EZH2 inhibition as a therapeutic strategy for lymphoma with EZH2-activating mutations. Nature. 2012; 492(7427):108112.

40. Qi W, Chan H, Teng L, Li L, Chuai S, Zhang R, Zeng J, Li M, Fan H, Lin Y, Gu J, Ardayfio O, Zhang JH, et al. Selective inhibition of Ezh2 by a small molecule inhibitor blocks tumor cells proliferation. Proceedings of the National Academy of Sciences of the United States of America. 2012; 109(52):21360-21365.

41. Akamatsu N, Yamada Y, Hasegawa H, Makabe K, Asano R, Kumagai I, Murata K, Imaizumi Y, Tsukasaki K, Tsuruda K, Sugahara K, Atogami S, Yanagihara K, et al. High IL21 receptor expression and apoptosis induction by IL-21 in follicular lymphoma. Cancer letters. 2007; 256(2):196-206.

42. Sarosiek KA, Malumbres R, Nechushtan H, Gentles AJ, Avisar E and Lossos IS. Novel IL-21 signaling pathway up-regulates c-Myc and induces apoptosis of diffuse large B-cell lymphomas. Blood. 2010; 115(3):570-580.

43. Yap DB, Chu J, Berg T, Schapira M, Cheng SW, Moradian A, Morin RD, Mungall AJ, Meissner B, Boyle M, Marquez VE, Marra MA, Gascoyne RD, et al. Somatic mutations at EZH2 Y641 act dominantly through a mechanism of selectively altered PRC2 catalytic activity, to increase H3K27 trimethylation. Blood. 2011; 117(8):2451-2459.

44. Guo S, Chan JK, Iqbal J, McKeithan T, Fu K, Meng B, Pan Y, Cheuk W, Luo D, Wang R, Zhang W, Greiner TC and Chan WC. EZH2 mutations in follicular lymphoma from different ethnic groups and associated gene expression alterations. Clinical cancer research. 2014; 20(12):30783086.

45. McCabe MT, Graves AP, Ganji G, Diaz E, Halsey WS, Jiang Y, Smitheman KN, Ott HM, Pappalardi MB, Allen KE, Chen SB, Della Pietra A, 3rd, Dul E, et al. Mutation of A677 in histone methyltransferase EZH2 in human B-cell lymphoma promotes hypertrimethylation of histone $\mathrm{H} 3$ on lysine 27 (H3K27). Proceedings of the National Academy of Sciences of the United States of America. 2012;
109(8):2989-2994.

46. Majer CR, Jin L, Scott MP, Knutson SK, Kuntz KW, Keilhack H, Smith JJ, Moyer MP, Richon VM, Copeland RA and Wigle TJ. A687V EZH2 is a gain-of-function mutation found in lymphoma patients. FEBS letters. 2012; 586(19):3448-3451.

47. Simon C, Chagraoui J, Krosl J, Gendron P, Wilhelm B, Lemieux S, Boucher G, Chagnon P, Drouin S, Lambert R, Rondeau C, Bilodeau A, Lavallee S, et al. A key role for EZH2 and associated genes in mouse and human adult T-cell acute leukemia. Genes \& development. 2012; 26(7):651-656.

48. Richter GH, Plehm S, Fasan A, Rossler S, Unland R, Bennani-Baiti IM, Hotfilder M, Lowel D, von Luettichau I, Mossbrugger I, Quintanilla-Martinez L, Kovar H, Staege MS, et al. EZH2 is a mediator of EWS/FLI1 driven tumor growth and metastasis blocking endothelial and neuroectodermal differentiation. Proceedings of the National Academy of Sciences of the United States of America. 2009; 106(13):5324-5329.

49. Fujii S, Fukamachi K, Tsuda $\mathrm{H}$, Ito $\mathrm{K}$, Ito $\mathrm{Y}$ and Ochiai A. RAS oncogenic signal upregulates EZH2 in pancreatic cancer. Biochemical and biophysical research communications. 2012; 417(3):1074-1079.

50. Fujii S, Tokita K, Wada N, Ito K, Yamauchi C, Ito Y and Ochiai A. MEK-ERK pathway regulates EZH2 overexpression in association with aggressive breast cancer subtypes. Oncogene. 2011; 30(39):4118-4128.

51. Volkel P, Dupret B, Le Bourhis X and Angrand PO. Diverse involvement of EZH2 in cancer epigenetics. American journal of translational research. 2015; 7(2):175-193.

52. Riquelme E, Behrens C, Lin HY, Simon G, Papadimitrakopoulou V, Izzo J, Moran C, Kalhor N, Lee JJ, Minna JD and Wistuba, II. Modulation of EZH2 Expression by MEK-ERK or PI3K-AKT Signaling in Lung Cancer Is Dictated by Different KRAS Oncogene Mutations. Cancer research. 2016; 76(3):675-685.

53. Santos M, Martinez-Fernandez M, Duenas M, GarciaEscudero R, Alfaya B, Villacampa F, Saiz-Ladera C, Costa C, Oteo M, Duarte J, Martinez V, Gomez-Rodriguez MJ, Martin ML, et al. In vivo disruption of an Rb-E2F-Ezh2 signaling loop causes bladder cancer. Cancer research. 2014; 74(22):6565-6577.

54. Coe BP, Thu KL, Aviel-Ronen S, Vucic EA, Gazdar AF, Lam S, Tsao MS and Lam WL. Genomic deregulation of the $\mathrm{E} 2 \mathrm{~F} / \mathrm{Rb}$ pathway leads to activation of the oncogene EZH2 in small cell lung cancer. PloS one. 2013; 8(8):e71670.

55. Chang CJ, Yang JY, Xia W, Chen CT, Xie X, Chao CH, Woodward WA, Hsu JM, Hortobagyi GN and Hung MC. EZH2 promotes expansion of breast tumor initiating cells through activation of RAF1-beta-catenin signaling. Cancer cell. 2011; 19(1):86-100.

56. Dong M, Fan XJ, Chen ZH, Wang TT, Li X, Chen J, Lin Q, Wen JY, Ma XK, Wei L, Ruan DY, Lin ZX, Liu Q, et 
al. Aberrant expression of enhancer of zeste homologue 2, correlated with HIF-1alpha, refines relapse risk and predicts poor outcome for breast cancer. Oncology reports. 2014; 32(3):1101-1107.

57. Bohrer LR, Chen S, Hallstrom TC and Huang H. Androgens suppress EZH2 expression via retinoblastoma (RB) and p130-dependent pathways: a potential mechanism of androgen-refractory progression of prostate cancer. Endocrinology. 2010; 151(11):5136-5145.

58. Chang CJ and Hung MC. The role of EZH2 in tumour progression. British journal of cancer. 2012; 106(2):243247.

59. Zhu Z, Tang J, Wang J, Duan G, Zhou L and Zhou X. MiR138 Acts as a Tumor Suppressor by Targeting EZH2 and Enhances Cisplatin-Induced Apoptosis in Osteosarcoma Cells. PloS one. 2016; 11(3):e0150026.

60. Zhuang C, Wang P, Huang D, Xu L, Wang X, Wang L and Hu L. A double-negative feedback loop between EZH2 and miR-26a regulates tumor cell growth in hepatocellular carcinoma. International journal of oncology. 2016; 48(3):1195-1204.

61. Smits M, Nilsson J, Mir SE, van der Stoop PM, Hulleman E, Niers JM, de Witt Hamer PC, Marquez VE, Cloos J, Krichevsky AM, Noske DP, Tannous BA and Wurdinger T. miR-101 is down-regulated in glioblastoma resulting in EZH2-induced proliferation, migration, and angiogenesis. Oncotarget. 2010; 1:710-720. doi: 10.18632/ oncotarget.101207.

62. Xiaoping L, Zhibin Y, Wenjuan L, Zeyou W, Gang X, Zhaohui L, Ying Z, Minghua W and Guiyuan L. CPEB1, a histone-modified hypomethylated gene, is regulated by miR-101 and involved in cell senescence in glioma. Cell death \& disease. 2013; 4:e675.

63. Sharma V, Purkait S, Takkar S, Malgulwar PB, Kumar A, Pathak P, Suri V, Sharma MC, Suri A, Kale SS, Kulshreshtha R and Sarkar C. Analysis of EZH2: microRNA network in low and high grade astrocytic tumors. Brain tumor pathology. 2016; 33(2):117-128.

64. Xu K, Wu ZJ, Groner AC, He HH, Cai C, Lis RT, Wu X, Stack EC, Loda M, Liu T, Xu H, Cato L, Thornton JE, et al. EZH2 oncogenic activity in castration-resistant prostate cancer cells is Polycomb-independent. Science (New York, NY). 2012; 338(6113):1465-1469.

65. Kim E, Kim M, Woo DH, Shin Y, Shin J, Chang N, Oh YT, Kim H, Rheey J, Nakano I, Lee C, Joo KM, Rich JN, et al. Phosphorylation of EZH2 activates STAT3 signaling via STAT3 methylation and promotes tumorigenicity of glioblastoma stem-like cells. Cancer cell. 2013; 23(6):839852.

66. Kaneko S, Li G, Son J, Xu CF, Margueron R, Neubert TA and Reinberg D. Phosphorylation of the PRC2 component Ezh2 is cell cycle-regulated and up-regulates its binding to ncRNA. Genes \& development. 2010; 24(23):2615-2620.

67. Wei Y, Chen YH, Li LY, Lang J, Yeh SP, Shi B, Yang CC,
Yang JY, Lin CY, Lai CC and Hung MC. CDK1-dependent phosphorylation of EZH2 suppresses methylation of H3K27 and promotes osteogenic differentiation of human mesenchymal stem cells. Nature cell biology. 2011; 13(1):87-94.

68. Hussain M, Rao M, Humphries AE, Hong JA, Liu F, Yang M, Caragacianu D and Schrump DS. Tobacco smoke induces polycomb-mediated repression of Dickkopf-1 in lung cancer cells. Cancer research. 2009; 69(8):3570-3578.

69. Lee TI, Jenner RG, Boyer LA, Guenther MG, Levine SS, Kumar RM, Chevalier B, Johnstone SE, Cole MF, Isono K, Koseki H, Fuchikami T, Abe K, et al. Control of developmental regulators by Polycomb in human embryonic stem cells. Cell. 2006; 125(2):301-313.

70. Li K, Liu C, Zhou B, Bi L, Huang H, Lin T and Xu K. Role of EZH2 in the growth of prostate cancer stem cells isolated from LNCaP cells. International journal of molecular sciences. 2013; 14(6):11981-11993.

71. Adhikary G, Grun D, Balasubramanian S, Kerr C, Huang JM and Eckert RL. Survival of skin cancer stem cells requires the Ezh2 polycomb group protein. Carcinogenesis. 2015; 36(7):800-810.

72. van Vlerken LE, Kiefer CM, Morehouse C, Li Y, Groves C, Wilson SD, Yao Y, Hollingsworth RE and Hurt EM. EZH2 is required for breast and pancreatic cancer stem cell maintenance and can be used as a functional cancer stem cell reporter. Stem cells translational medicine. 2013; 2(1):43-52.

73. Chen Q, Zheng PS and Yang WT. EZH2-mediated repression of GSK-3beta and TP53 promotes Wnt/betacatenin signaling-dependent cell expansion in cervical carcinoma. Oncotarget. 2016; 7:36115-36129. doi: 10.18632/oncotarget.8741.

74. Galvis LA, Holik AZ, Short KM, Pasquet J, Lun AT, Blewitt ME, Smyth IM, Ritchie ME and Asselin-Labat ML. Repression of Igf1 expression by Ezh2 prevents basal cell differentiation in the developing lung. Development (Cambridge, England). 2015; 142(8):1458-1469.

75. Liu T, Hou L and Huang Y. EZH2-specific microRNA-98 inhibits human ovarian cancer stem cell proliferation via regulating the pRb-E2F pathway. Tumour biology. 2014; 35(7):7239-7247.

76. Yan M, Zhang Y, He B, Xiang J, Wang ZF, Zheng FM, Xu J, Chen MY, Zhu YL, Wen HJ, Wan XB, Yue CF, Yang N, et al. IKKalpha restoration via EZH2 suppression induces nasopharyngeal carcinoma differentiation. Nature communications. 2014; 5:3661.

77. Chen JF, Luo X, Xiang LS, Li HT, Zha L, Li N, He JM, Xie GF, Xie X and Liang HJ. EZH2 promotes colorectal cancer stem-like cell expansion by activating p21cip1-Wnt/ beta-catenin signaling. Oncotarget. 2016; 7:41540-41558. doi: 10.18632/oncotarget.9236.

78. Zhu J, Yang DR, Sun Y, Qiu X, Chang HC, Li G, Shan $\mathrm{Y}$ and Chang C. TR4 Nuclear Receptor Alters the Prostate 
Cancer CD133+ Stem/Progenitor Cell Invasion via Modulating the EZH2-Related Metastasis Gene Expression. Molecular cancer therapeutics. 2015; 14(6):1445-1453.

79. Danis E, Yamauchi T, Echanique K, Zhang X, Haladyna JN, Riedel SS, Zhu N, Xie H, Orkin SH, Armstrong SA, Bernt KM and Neff T. Ezh2 Controls an Early Hematopoietic Program and Growth and Survival Signaling in Early T Cell Precursor Acute Lymphoblastic Leukemia. Cell reports. 2016; 14(8):1953-1965.

80. Zhang J, Chen L, Han L, Shi Z, Zhang J, Pu P and Kang C. EZH2 is a negative prognostic factor and exhibits prooncogenic activity in glioblastoma. Cancer letters. 2015; 356(2 Pt B):929-936.

81. Orlando G, Khoronenkova SV, Dianova, II, Parsons JL and Dianov GL. ARF induction in response to DNA strand breaks is regulated by PARP1. Nucleic acids research. 2014; 42(4):2320-2329.

82. Ma DN, Chai ZT, Zhu XD, Zhang N, Zhan DH, Ye BG, Wang CH, Qin CD, Zhao YM, Zhu WP, Cao MQ, Gao DM, Sun HC, et al. MicroRNA-26a suppresses epithelialmesenchymal transition in human hepatocellular carcinoma by repressing enhancer of zeste homolog 2. Journal of hematology \& oncology. 2016; 9:1.

83. Cao Q, Yu J, Dhanasekaran SM, Kim JH, Mani RS, Tomlins SA, Mehra R, Laxman B, Cao X, Yu J, Kleer CG, Varambally $\mathrm{S}$ and Chinnaiyan AM. Repression of E-cadherin by the polycomb group protein EZH2 in cancer. Oncogene. 2008; 27(58):7274-7284.

84. Wang J, Zhu X, Hu J, He G, Li X, Wu P, Ren X, Wang F, Liao W, Liang L and Ding Y. The positive feedback between Snail and DAB2IP regulates EMT, invasion and metastasis in colorectal cancer. Oncotarget. 2015; 6:2742727439. doi: 10.18632/oncotarget.4861.

85. Smits M, van Rijn S, Hulleman E, Biesmans D, van Vuurden DG, Kool M, Haberler C, Aronica E, Vandertop WP, Noske DP and Wurdinger T. EZH2-regulated DAB2IP is a medulloblastoma tumor suppressor and a positive marker for survival. Clinical cancer research. 2012; 18(15):4048-4058.

86. Shi B, Liang J, Yang X, Wang Y, Zhao Y, Wu H, Sun L, Zhang Y, Chen Y, Li R, Zhang Y, Hong M and Shang $\mathrm{Y}$. Integration of estrogen and Wnt signaling circuits by the polycomb group protein EZH2 in breast cancer cells. Molecular and cellular biology. 2007; 27(14):5105-5119.

87. Lee ST, Li Z, Wu Z, Aau M, Guan P, Karuturi RK, Liou YC and Yu Q. Context-specific regulation of NF-kappaB target gene expression by EZH2 in breast cancers. Molecular cell. 2011; 43(5):798-810.

88. Min J, Zaslavsky A, Fedele G, McLaughlin SK, Reczek EE, De Raedt T, Guney I, Strochlic DE, Macconaill LE, Beroukhim R, Bronson RT, Ryeom S, Hahn WC, et al. An oncogene-tumor suppressor cascade drives metastatic prostate cancer by coordinately activating Ras and nuclear factor-kappaB. Nature medicine. 2010; 16(3):286-294.
89. Xu Z, Sun Y, Guo Y, Qin G, Mu S, Fan R, Wang B, Gao W, $\mathrm{Wu} \mathrm{H}$, Wang $\mathrm{G}$ and Zhang Z. NF-YA promotes invasion and angiogenesis by upregulating EZH2-STAT3 signaling in human melanoma cells. Oncology reports. 2016; 35(6):3630-3638.

90. Gunawan M, Venkatesan N, Loh JT, Wong JF, Berger H, Neo WH, Li LY, La Win MK, Yau YH, Guo T, See PC, Yamazaki S, Chin KC, et al. The methyltransferase Ezh2 controls cell adhesion and migration through direct methylation of the extranuclear regulatory protein talin. Nature immunology. 2015; 16(5):505-516.

91. Peng D, Kryczek I, Nagarsheth N, Zhao L, Wei S, Wang W, Sun Y, Zhao E, Vatan L, Szeliga W, Kotarski J, Tarkowski R, Dou Y, et al. Epigenetic silencing of TH1-type chemokines shapes tumour immunity and immunotherapy. Nature. 2015; 527(7577):249-253.

92. Nagarsheth N, Peng D, Kryczek I, Wu K, Li W, Zhao E, Zhao L, Wei S, Frankel T, Vatan L, Szeliga W, Dou Y, Owens S, et al. PRC2 Epigenetically Silences Th1-Type Chemokines to Suppress Effector T-Cell Trafficking in Colon Cancer. Cancer research. 2016; 76(2):275-282.

93. Yin J, Leavenworth JW, Li Y, Luo Q, Xie H, Liu X, Huang S, Yan H, Fu Z, Zhang LY, Zhang L, Hao J, Wu X, et al. Ezh2 regulates differentiation and function of natural killer cells through histone methyltransferase activity. Proceedings of the National Academy of Sciences of the United States of America. 2015; 112(52):15988-15993.

94. Hayashi S, Kumai T, Matsuda Y, Aoki N, Sato K, Kimura S, Kitada M, Tateno M, Celis E and Kobayashi H. Sixtransmembrane epithelial antigen of the prostate and enhancer of zeste homolog 2 as immunotherapeutic targets for lung cancer. Journal of translational medicine. 2011; 9:191.

95. Yang XP, Jiang K, Hirahara K, Vahedi G, Afzali B, Sciume G, Bonelli M, Sun HW, Jankovic D, Kanno Y, Sartorelli V, O'Shea JJ and Laurence A. EZH2 is crucial for both differentiation of regulatory $\mathrm{T}$ cells and $\mathrm{T}$ effector cell expansion. Scientific reports. 2015; 5:10643.

96. Zhao E, Maj T, Kryczek I, Li W, Wu K, Zhao L, Wei S, Crespo J, Wan S, Vatan L, Szeliga W, Shao I, Wang Y, et al. Cancer mediates effector $\mathrm{T}$ cell dysfunction by targeting microRNAs and EZH2 via glycolysis restriction. Nature immunology. 2016; 17(1):95-103.

97. DuPage M, Chopra G, Quiros J, Rosenthal WL, Morar MM, Holohan D, Zhang R, Turka L, Marson A and Bluestone JA. The chromatin-modifying enzyme Ezh2 is critical for the maintenance of regulatory $\mathrm{T}$ cell identity after activation. Immunity. 2015; 42(2):227-238.

98. Liu VC, Wong LY, Jang T, Shah AH, Park I, Yang X, Zhang Q, Lonning S, Teicher BA and Lee C. Tumor evasion of the immune system by converting CD4+CD25$\mathrm{T}$ cells into $\mathrm{CD} 4+\mathrm{CD} 25+\mathrm{T}$ regulatory cells: role of tumorderived TGF-beta. Journal of immunology (Baltimore, Md : 1950). 2007; 178(5):2883-2892.

99. Adeegbe DO and Nishikawa H. Natural and induced T 
regulatory cells in cancer. Frontiers in immunology. 2013; 4:190.

100. Curiel TJ, Coukos G, Zou L, Alvarez X, Cheng P, Mottram P, Evdemon-Hogan M, Conejo-Garcia JR, Zhang L, Burow M, Zhu Y, Wei S, Kryczek I, et al. Specific recruitment of regulatory $\mathrm{T}$ cells in ovarian carcinoma fosters immune privilege and predicts reduced survival. Nature medicine. 2004; 10(9):942-949.

101. Viguier M, Lemaitre F, Verola O, Cho MS, Gorochov G, Dubertret L, Bachelez H, Kourilsky P and Ferradini L. Foxp3 expressing CD4+CD25(high) regulatory $\mathrm{T}$ cells are overrepresented in human metastatic melanoma lymph nodes and inhibit the function of infiltrating T cells. Journal of immunology (Baltimore, Md : 1950). 2004; 173(2):14441453.

102. Uso M, Jantus-Lewintre E, Bremnes RM, Calabuig S, Blasco A, Pastor E, Borreda I, Molina-Pinelo S, Paz-Ares L, Guijarro R, Martorell M, Forteza J, Camps C, et al. Analysis of the immune microenvironment in resected nonsmall cell lung cancer: the prognostic value of different $\mathrm{T}$ lymphocyte markers. Oncotarget. 2016; 7:52849-52861. doi: 10.18632/oncotarget.10811.

103. Wang Y, Sun J, Zheng R, Shao Q, Gao W, Song B, Chen X and $\mathrm{Qu}$ X. Regulatory $\mathrm{T}$ cells are an important prognostic factor in breast cancer: a systematic review and metaanalysis. Neoplasma. 2016; 63(5).

104. Sia KC, Huynh H, Chung AY, Ooi LL, Lim KH, Hui KM and Lam PY. Preclinical evaluation of transcriptional targeting strategy for human hepatocellular carcinoma in an orthotopic xenograft mouse model. Molecular cancer therapeutics. 2013; 12(8):1651-1664.

105. Sha M, Mao G, Wang G, Chen Y, Wu X and Wang Z. DZNep inhibits the proliferation of colon cancer HCT116 cells by inducing senescence and apoptosis. Acta pharmaceutica Sinica B. 2015; 5(3):188-193.

106. Balasubramanian S, Adhikary G and Eckert RL. The Bmi1 polycomb protein antagonizes the (-)-epigallocatechin-3gallate-dependent suppression of skin cancer cell survival. Carcinogenesis. 2010; 31(3):496-503.

107. Lin YH, Lee CC, Chang FR, Chang WH, Wu YC and Chang JG. 16-hydroxycleroda-3,13-dien-15,16-olide regulates the expression of histone-modifying enzymes PRC2 complex and induces apoptosis in CML K562 cells. Life sciences. 2011; 89(23-24):886-895.

108. Bao B, Ali S, Banerjee S, Wang Z, Logna F, Azmi AS, Kong D, Ahmad A, Li Y, Padhye S and Sarkar FH. Curcumin analogue CDF inhibits pancreatic tumor growth by switching on suppressor microRNAs and attenuating EZH2 expression. Cancer research. 2012; 72(1):335-345.

109. Kim W, Bird GH, Neff T, Guo G, Kerenyi MA, Walensky LD and Orkin SH. Targeted disruption of the EZH2-EED complex inhibits EZH2-dependent cancer. Nature chemical biology. 2013; 9(10):643-650.

110. Kong X, Chen L, Jiao L, Jiang X, Lian F, Lu J, Zhu K,
Du D, Liu J, Ding H, Zhang N, Shen J, Zheng M, et al. Astemizole arrests the proliferation of cancer cells by disrupting the EZH2-EED interaction of polycomb repressive complex 2. Journal of medicinal chemistry. 2014; 57(22):9512-9521.

111. Verma SK, Tian X, LaFrance LV, Duquenne C, Suarez DP, Newlander KA, Romeril SP, Burgess JL, Grant SW, Brackley JA, Graves AP, Scherzer DA, Shu A, et al. Identification of Potent, Selective, Cell-Active Inhibitors of the Histone Lysine Methyltransferase EZH2. ACS medicinal chemistry letters. 2012; 3(12):1091-1096.

112. Wu C, Jin X, Yang J, Yang Y, He Y, Ding L, Pan Y, Chen $\mathrm{S}$, Jiang $\mathrm{J}$ and Huang $\mathrm{H}$. Inhibition of EZH2 by chemo- and radiotherapy agents and small molecule inhibitors induces cell death in castration-resistant prostate cancer. Oncotarget. 2016; 7:3440-3452. doi: 10.18632/oncotarget.6497.

113. Tiffen JC, Gunatilake D, Gallagher SJ, Gowrishankar K, Heinemann A, Cullinane C, Dutton-Regester K, Pupo GM, Strbenac D, Yang JY, Madore J, Mann GJ, Hayward NK, et al. Targeting activating mutations of EZH2 leads to potent cell growth inhibition in human melanoma by derepression of tumor suppressor genes. Oncotarget. 2015; 6:2702327036. doi: 10.18632/oncotarget.4809.

114. Chen YT, Zhu F, Lin WR, Ying RB, Yang YP and Zeng LH. The novel EZH2 inhibitor, GSK126, suppresses cell migration and angiogenesis via down-regulating VEGF-A. Cancer chemotherapy and pharmacology. 2016; 77(4):757765.

115. Campbell JE, Kuntz KW, Knutson SK, Warholic NM, Keilhack H, Wigle TJ, Raimondi A, Klaus CR, Rioux N, Yokoi A, Kawano S, Minoshima Y, Choi HW, et al. EPZ011989, A Potent, Orally-Available EZH2 Inhibitor with Robust in Vivo Activity. ACS medicinal chemistry letters. 2015; 6(5):491-495.

116. Song X, Gao T, Wang N, Feng Q, You X, Ye T, Lei Q, Zhu Y, Xiong M, Xia Y, Yang F, Shi Y, Wei Y, et al. Selective inhibition of EZH2 by ZLD1039 blocks H3K27methylation and leads to potent anti-tumor activity in breast cancer. Scientific reports. 2016; 6:20864.

117. Knutson SK, Kawano S, Minoshima Y, Warholic NM, Huang KC, Xiao Y, Kadowaki T, Uesugi M, Kuznetsov G, Kumar N, Wigle TJ, Klaus CR, Allain CJ, et al. Selective inhibition of EZH2 by EPZ-6438 leads to potent antitumor activity in EZH2-mutant non-Hodgkin lymphoma. Molecular cancer therapeutics. 2014; 13(4):842-854.

118. Alimova I, Birks DK, Harris PS, Knipstein JA, Venkataraman S, Marquez VE, Foreman NK and Vibhakar R. Inhibition of EZH2 suppresses self-renewal and induces radiation sensitivity in atypical rhabdoid teratoid tumor cells. Neuro-oncology. 2013; 15(2):149-160.

119. Xia H, Yu CH, Zhang Y, Yu J, Li J, Zhang W, Zhang B, Li Y and Guo N. EZH2 silencing with RNAi enhances irradiation-induced inhibition of human lung cancer growth in vitro and in vivo. Oncology letters. 2012; 4(1):135-140.

120. Fillmore CM, Xu C, Desai PT, Berry JM, Rowbotham SP, 
Lin YJ, Zhang H, Marquez VE, Hammerman PS, Wong KK and Kim CF. EZH2 inhibition sensitizes BRG1 and EGFR mutant lung tumours to TopoII inhibitors. Nature. 2015; 520(7546):239-242.

121. Smonskey M, Lasorsa E, Rosario S, Kirk JS, HernandezIlizaliturri FJ and Ellis L. EZH2 inhibition re-sensitizes multidrug resistant B-cell lymphomas to etoposide mediated apoptosis. Oncoscience. 2016; 3(1):21-30.

122. Kirk JS, Schaarschuch K, Dalimov Z, Lasorsa E, Ku S, Ramakrishnan S, Hu Q, Azabdaftari G, Wang J, Pili R and Ellis L. Top2a identifies and provides epigenetic rationale for novel combination therapeutic strategies for aggressive prostate cancer. Oncotarget. 2015; 6:3136-3146. doi: 10.18632/oncotarget.3077.

123. Neo WH, Lim JF, Grumont R, Gerondakis S and Su IH. c-Rel regulates Ezh2 expression in activated lymphocytes and malignant lymphoid cells. The Journal of biological chemistry. 2014; 289(46):31693-31707.

124. Su KJ, Lin CW, Chen MK, Yang SF and Yu YL. Effects of EZH2 promoter polymorphisms and methylation status on oral squamous cell carcinoma susceptibility and pathology. American journal of cancer research. 2015; 5(11):34753484.

125. Yu YL, Su KJ, Hsieh MJ, Wang SS, Wang PH, Weng WC and Yang SF. Impact of EZH2 polymorphisms on urothelial cell carcinoma susceptibility and clinicopathologic features. PloS one. 2014; 9(4):e93635.

126. Yu YL, Su KJ, Hsieh YH, Lee HL, Chen TY, Hsiao PC and Yang SF. Effects of EZH2 polymorphisms on susceptibility to and pathological development of hepatocellular carcinoma. PloS one. 2013; 8(9):e74870.

127. Wang J, Ma ZB, Li K and Guo GH. Association between EZH2 polymorphisms and colorectal cancer risk in Han Chinese population. Medical oncology (Northwood,
London, England). 2014; 31(3):874.

128. Ma ZB, Guo GH, Niu Q and Shi N. Role of EZH2 polymorphisms in esophageal squamous cell carcinoma risk in Han Chinese population. International journal of molecular sciences. 2014; 15(7):12688-12697.

129. Zhou Y, Du WD, Wu Q, Liu Y, Chen G, Ruan J, Xu S, Yang F, Zhou FS, Tang XF, Tang HY, Zuo XB, Zhang FY, et al. EZH2 genetic variants affect risk of gastric cancer in the Chinese Han population. Molecular carcinogenesis. 2014; 53(8):589-597.

130. Paolicchi E, Pacetti P, Giovannetti E, Mambrini A, Orlandi M, Crea F, Romani AA, Tartarini R, Danesi R, Peters GJ and Cantore M. A single nucleotide polymorphism in EZH2 predicts overall survival rate in patients with cholangiocarcinoma. Oncology letters. 2013; 6(5):14871491.

131. Crea F, Fornaro L, Paolicchi E, Masi G, Frumento P, Loupakis F, Salvatore L, Cremolini C, Schirripa M, Graziano F, Ronzoni M, Ricci V, Farrar WL, et al. An EZH2 polymorphism is associated with clinical outcome in metastatic colorectal cancer patients. Annals of oncology. 2012; 23(5):1207-1213.

132. Gao SB, Sun SL, Zheng QL, Zhang L, Zhu Y, Jin GH and Xue LX. Genetic alteration and misexpression of Polycomb group genes in hepatocellular carcinoma. American journal of cancer research. 2015; 5(10):2969-2979.

133. Yoon KA, Gil HJ, Han J, Park J and Lee JS. Genetic polymorphisms in the polycomb group gene EZH2 and the risk of lung cancer. Journal of thoracic oncology. 2010; 5(1):10-16. 